\title{
Comic Strips as Environmental Educative Tools for the Alaotra Region
}

\author{
Claudette P. Maminirina', Pascal Girod" and Patrick O. \\ Waeber'
}

\begin{abstract}
The Alaotra Gentle Lemur (Hapalemur griseus alaotrensis) is one of the most endangered lemurs of Madagascar. The wild population struggles for survival in the rapidly disappearing papyrus marshes fringing Lake Alaotra, northeastern Madagascar. The current estimated population size of the Alaotra lemurs is about 3,000 individuals. The largest subpopulations left are found in the marshes around the four villages of Andreba, Ambodivoara, Andilana Sud and Anororo. These sites constitute the main focus of Madagascar Wildlife Conservation's (MWC) environmental education project. In a test phase lasting from November 2006 -February 2007, eight primary school classes will implement a series of educative comic strips dealing with the complexity of the Alaotra lake and marshy ecosystem. The aim of this teaching method is to raise the awareness of the schoolchildren about the importance and significance of their natural environment.
\end{abstract}

\section{INTRODUCTION}

THE WETLAND'S VALUES The wetlands of the Lake

Alaotra are known for their complex ecosystems including the reed and papyrus beds which are home to a rich animal community including 72 species of birds and the Alaotra Gentle Lemur (Hapalemur griseus alaotrensis), also known as the "Bandro", a species of lemur endemic to the region. The marshes surrounding the lake have several substantial functions and are of fundamental importance for the fauna inhabiting them and for the human population of the basin (Pidgeon 1996). The vegetation serves as a refuge and safe breeding ground for fish and also acts as a natural filter reducing pollution of the lake by breaking down chemicals used in rice production. Furthermore, the marshes store humidity during the dry season benefiting the adjacent rice fields and in turn prevent flooding during annual periods of high rainfall.

ENDANGERED BANDRO The increasing human activity around Lake Alaotra has resulted in a severe loss and fragmentation of natural habitats. Combined with pressures from hunting and fishing, these activities are threatening the survival of many local animal species. The endemic Alaotra Grebe (Tachybaptus rufolavatus) and Madagascar Pochard (Aythya innotata) might already have gone extinct (Pidgeon 1996) and the Alaotra Gentle Lemur is struggling for survival. While in 199011,000
Correspondence:

Patrick O. Waeber

Madagascar Wildlife Conservation

Anthropological Institute and Museum, University of Zurich

$\mathrm{CH}-8057$ Zurich

Switzerland

E-mail: madagascar@mwc-info.net

individuals were counted (Mutschler and Feistner 1995), today only 2,500-3,500 remain, mostly in isolated subpopulations. If the population continues to decline at this pace, the Bandro will be extinct in less than 40 years (Ralainasolo 2004).

AIMS OF THE PROJECT TO promote a public sensitiv

ity for the importance of an intact and healthy habitat for certain species, MWC will implement an environmental education programme in the primary schools (EPP) of the region. In order to make learning more interactive and exciting and teaching easier, MWC has chosen to use comic strips as environmental educative tools. A comic book about the importance and peculiarities of lemurs has been tried and tested in other parts of Madagascar (Vaucoulon 1990). However, to cope with the specialities of the Alaotra region, Madagascar Wildlife Conservation aims to develop and publish a comic with the regional characteristics.

There are several long-term goals for this project. First, to widen the horizon and the knowledge of the school children and future adults on the complexity of the natural and agro-cultural environment of the Alaotra region. Second, to help these young people to appreciate their own environment and to encourage them to share what they learn with their respective communities. Third, to point out the links between people's activities and the natural resources of their region. And finally, to become actively responsible for the specialities of their living space and resources and to enable them to protect, to improve and to conserve the productivity of their land.

\section{BACKGROUND}

THE REGION OF ALAOTRA Lake Alaotra is the largest lake

in Madagascar and is surrounded by a vast wetland area consisting of marshes and rice fields (Nicoll and Langrand 1989). Due to the high productivity of these wetlands, the Alaotra basin is known as the "Grenier de Madagascar" (Granary of Madagascar), producing one third of the annual rice harvest of the country (Pidgeon 1996). Moreover, Lake Alaotra provides the highest amount of sweet water fish in Madagascar: In 2004 2,400 tonnes and in 2005 2,700 tonnes of fish were caught for export to other Malagasy regions, mainly to the capital Antananarivo (Randriamanolosoa Jean, Centre de Surveillences des pêches Ambatondrazaka, pers. com.). 50 years ago, about 100,000 
people lived in this region (Trappe 1987). By 2004, 673,493 people had settled in the region (Démographie 2004).

THE MARSHES UNDER PRESSURE In the last 50 years, the marshes have suffered from an extensive destruction due to the increasing use of these natural resources by humans. For example, large areas have been burnt and transformed into new rice fields. Additionally, the papyrus and reed beds provide the traditional material for the construction of the typical Sihanaka houses, as well as for the weaving products. Lake Alaotra is bordered on two sides by hill chains, which today have been completely deforested for the gain of agricultural and pasture land. Unprotected by the forest, the soil of the hills is washed away during the rainy season and the mud is transported by the rivers towards the marshes, where rice fields are destroyed and irrigation systems silted up (Bakoariniaina et al. 2006). The sediments that are not retained by the destroyed papyrus and reed beds are carried into the lake, covering its bed with a thick layer of mud and resulting in an increased water level (Moreau 1987, Pidgeon 1996). The shoreline has also been recorded to advance continually (more than three meters between 1915 and 1974 (Moreau 1987), leading to a decrease in the open water surface of the lake. Within the past 30 years, the lake has lost about five $\mathrm{km}^{2}$ of its size (Bakoariniaina et al. 2006).

EDUCATIONAL SYSTEM IN THE ALAOTRA REGION

The Alaotra-Mangoro region (see Figure 1) is divided into five sub-regions or districts: Ambatondrazaka, Amparafaravola, Andilamena, Moramanga and Anosibe An'ala. In 2004, children in the age group of 6-14 years old represented $27 \%$ (or 300,389 people) of the population of the Alaotra-Mangoro region. $18 \%$ of these children were not formally educated due to lack of schools (Education 2004). Furthermore, there is no school obligation, hence it is up to the parents to send their children to school or not.

The Alaotra region is represented by the two districts Ambatondrazaka and Amparafaravola, which cover a surface of 13,463 $\mathrm{km}^{2}$ (Population 2004). Each district has 20 townships containing several villages. The number of establishments for both districts is similar, with an average of 12 primary schools per township. The internal structure of primary schools is presented in Table 1.

In the Alaotra primary schools, there are on average 44 pupils per class and teacher. It is noted that there is a large imbalance for public schools with 47 pupils per teacher and private schools with 32 pupils per teacher. Furthermore, where the number of teachers in public schools is very low and therefore the number of pupils even exceeds the mentioned average, the chief of the administrative and educational zone (Chef ZAP: Zone Administrative et Pédagogique) and the pupil's parents association recruit additional teachers (often not professionals) and finance their small wages. Such associations make regular school attendance for the children more feasible.

For every school there are five levels of classes starting at level eleven and finishing with level seven. One school year lasts nine months from September to June. Pupils are examined every two months on all the taught courses. The school programme, which is administered by the Ministry of Education, embraces up to eleven subjects, such as French, Arithmetic, Malagasy, Recitation, Music, Drawing, Writing, Sport and during the last two years also Geography, General Knowledge and History. This highlights that, until now, there has been no environmental education program at the level of primary school in this region.

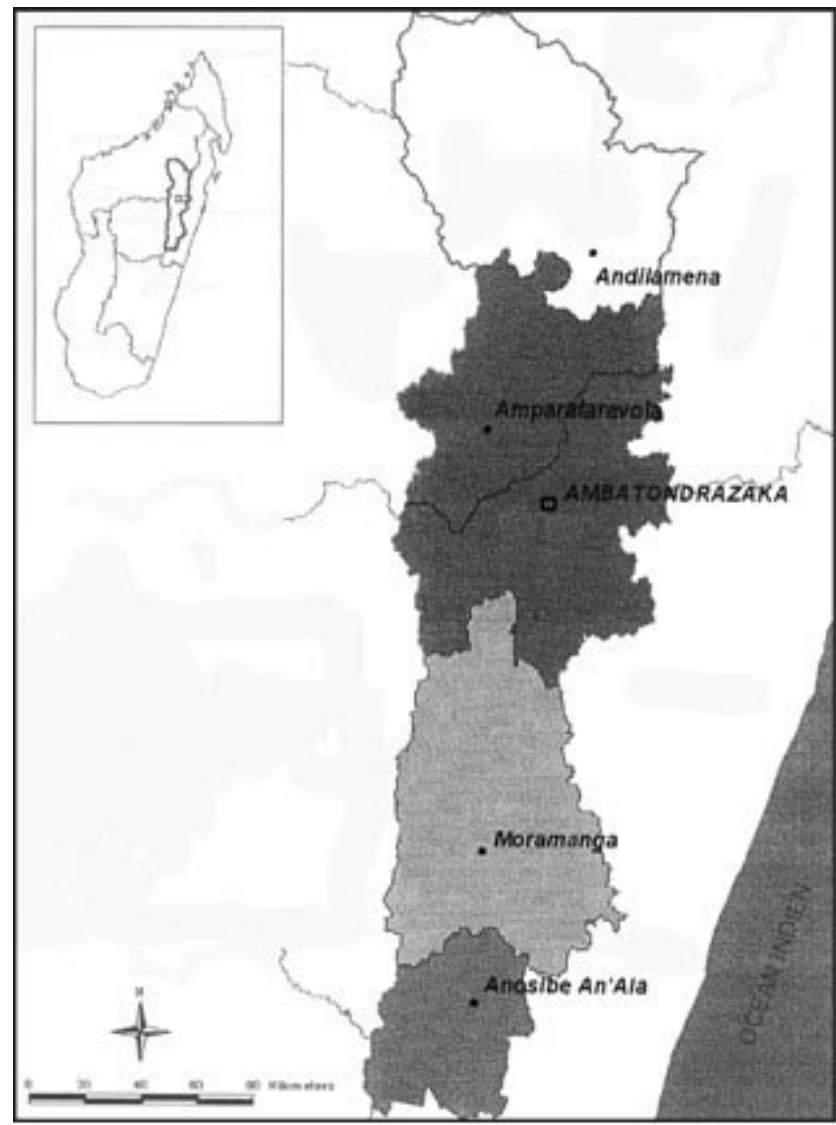

FIGURE 1. The 5 districts of the Alaotra-Mangoro region. Adapted from: FTM, Monographies des Districts 2004 (with kind permission of UGI Région Alaotra-Mangoro)

THE COMIC BOOK APPROACH The comic developed by MWC is divided into eight different thematic episodes (see Table 2) such as hunting, lemurs as pets, the importance of an intact marshy habitat, or the consequence of fires. An episode consists of 12-24 pictures, is written in Malagasy and has its own theme and conservation message. The titles of the episodes already contain the central message. The main characters in the comic strip will be an Alaotra Gentle Lemur called Malala (Malagasy, meaning 'sweet'), a Kingfisher called Haja (Malagasy, meaning 'respect') and a Mellers duck called Solofo (Malagasy, meaning 'generation') as representatives of the wildlife. The villagers' point of view will be represented by two girls (Felana and Lalao) and two boys (Fidy and Tefy).

Using these characters (see Figure 2) has several advantages. First, it is possible to show that both humans and wildlife have their own important uses, and hence often compete, for the same resources (e.g., papyrus stems: humans use them as basketry material, wildlife use them as food). Second, depending on the theme and/or cultural situation, it is more appropriate to have girls than boys or vice versa playing a scene (e.g., it is mostly boys that go fishing). The same method and approach is valuable for the wildlife. For example a Kingfisher can represent an expert of fishes whereas a Gentle lemur knows certainly more about papyrus and reed grass. Furthermore, by having the Alaotra lemur or the Mellers duck as main characters, the peculiarity of the fauna can be directly demonstrated and discussed.

Every school child will receive their own personal black and white copy of the comic containing all episodes. They can 
TABLE 1. Showing numbers on the Alaotra districts, schools, enrolled school children and teachers (from CISCO, Monographie des Districts, zones de planification 2004 (school year 2003-2004). In Plan Régional de développement Alaotra-Mangoro).

\begin{tabular}{|l|c|c|c|c|c|c|}
\hline \multirow{2}{*}{ DISTRICTS } & \multicolumn{2}{|c|}{ NUMBER OF ESTABLISHMENTS } & \multicolumn{2}{c|}{ Enrolled school children } & Private & Public \\
\hline & Public & Private & Public & 7,560 & 794 \\
\hline Ambatondrazaka & 212 & 35 & 40,738 & 5,262 & 196 \\
\hline Amparafaravola & 216 & 39 & 40,393 & 12,822 & 1,720 \\
\hline Alaotra region & 428 & 74 & 81,131 & 398 \\
\hline
\end{tabular}

TABLE 2. The first column represents the title of an episode (=main message); the second column shows the discussed theme and the third column gives possible additional educative material for the teachers.

\begin{tabular}{|c|c|c|}
\hline TITLE OF AN EPISODE & DISCUSSED THEME IN AN EPISODE & $\begin{array}{l}\text { SUPPLEMENTARY MATERIAL FOR } \\
\text { TEACHERS }\end{array}$ \\
\hline Everyone needs the reed and papyrus beds & Bandro Biology & $\begin{array}{l}\text { Locomotion of Lemurs } \\
\text { Marsh Plants (Reed; Papyrus) }\end{array}$ \\
\hline There is no possibility to hide in the rice paddies & Bandros are at home in the marshes & $\begin{array}{l}\text { Rice cultivation methods } \\
\text { Importance of the region as 'grenier de } \\
\text { Madagascar' }\end{array}$ \\
\hline Problems in finding a life partner & Habitat fragmentation & $\begin{array}{l}\text { Social structure of the Bandro, migration } \\
\text { Biology of reed and papyrus } \\
\text { Fire and the regeneration process of reed }\end{array}$ \\
\hline Without marshes no more fish & $\begin{array}{l}\text { Reed and papyrus is an important breeding ground } \\
\text { for fishes to maintain the fish stock of the lake }\end{array}$ & $\begin{array}{l}\text { Fish species of Alaotra } \\
\text { Alien Fish species and consequences } \\
\text { Biology: from egg to fish } \\
\text { The need for a Fishing-restriction in November }\end{array}$ \\
\hline Bandros are not pets & $\begin{array}{l}\text { Bandros cannot survive in captivity without the } \\
\text { appropriate food }\end{array}$ & $\begin{array}{l}\text { Differences between domestic, useful and wild } \\
\text { animals }\end{array}$ \\
\hline $\begin{array}{l}\text { The Bandros are protected by } \\
\text { Malagasy law }\end{array}$ & We should not hunt Bandros & $\begin{array}{l}\text { Natural enemies of the Bandro } \\
\text { Why are species protected }\end{array}$ \\
\hline We plant trees & Sand is fatal for the lake and for the rice paddies & $\begin{array}{l}\text { The role of forests in a landscape } \\
\text { Consequences of degradation and erosion for } \\
\text { agricultural output }\end{array}$ \\
\hline Bandros only exists at Lake Alaotra & $\begin{array}{l}\text { Tourists are coming from far away to see the } \\
\text { Bandro }\end{array}$ & $\begin{array}{l}\text { Lemurs of Madagascar } \\
\text { Endemic species to Alaotra }\end{array}$ \\
\hline
\end{tabular}

colour it (if pencils are available) and they can take it home and show it to other people.

The episodes are interesting and often humorous but also concise and they transmit only one central message. This message is stated as the title of each episode. The more clearly this central message is directed to the children, the more memorable and long-lasting it will be.

By using dialog of the characters together (e.g., the animal characters are also able to 'speak'), the real and daily life problems can be addressed in a manner that allows children to understand it.

As the comic's girls and boys show different characteristics, real children can identify with their respective counterparts in the comic strips. To further facilitate and deepen the identification between the readers and the characters in the comic, the comic-children are aged between six and eleven years and the stories are written and presented close to reality or real-life situations that children may encounter.

MATERIAL FOR THE TEACHERS In the issues, problems such as destruction of habitat or hunting are introduced and possible reasons for such activities are discussed. However, direct solutions to problems or specific alternatives are not presented. For deeper understanding of the very complex theme, the teachers will receive supplemen- tary educative material for creating the lessons to accompany each issue.

An issue is the starting point for a class discussion or a class activity (e.g. , a theatre play or a boat trip in the marshes). It can also function as a promoter of a more elaborate theme such as "Iemurs and endemism", or the natural function of a tropical rainforest.

\section{METHODOLOGY}

Prior to the comic strip going into production, the storyboards will be checked by Malagasy conservationists and students for regional cultural consistency. It should be a comic designed especially for the Alaotra region and therefore only typical and specific cultural elements from this region should be presented. In a follow up stage, the books as well as the copies for the children will be produced and printed in Madagascar. MWC will distribute paperbacks of the comic strips to the teachers.

In a test phase the comic will be introduced to eight classes (452 children, see Table 3) in four selected villages (Andreba, Ambodivoara, Andilana Sud and Anororo). Beforehand the eight teachers of these classes will be trained in Ambatondrazaka by a Conservation Instructor of the "Parc Ivoloina" (Madagascar Fauna Group), MWC and the CISCO (Circonscription Scolaire, the school authorities) on topics such as Malagasy biodiversity, 
TABLE 3. The 8 test-classes presented by village. $C E=9^{\text {th }}, C M=8^{\text {th }}$ level; (chosen in the school year 2005-2006); the age of the pupils varies for the CE level from $9-11$ years and for the CM level from $10-12$ years.

\begin{tabular}{|c|c|c|c|}
\hline VILLAGE & TEACHER & SCHOOL LEVEL & NUMBER OF PUPILS \\
\hline \multirow{2}{*}{ Andreba } & Mme Razanamihamina & $C E$ & 35 \\
\hline & Mme Razanarivo Meltine & $\mathrm{CE}$ & 35 \\
\hline \multirow{2}{*}{ Ambodivoara } & Mlle Ranantenainasoa Louisette & $\mathrm{CE}$ & 43 \\
\hline & Mr Randriamiarizaka Tolinirina Media & CE & 43 \\
\hline \multirow{2}{*}{ Andilana Sud } & Mme Rabeby & $\mathrm{CE}$ & 73 \\
\hline & Mme Razafimanarivo Marie Augustine & $\mathrm{CM}$ & 27 \\
\hline \multirow{2}{*}{ Anororo } & Mlle Rasoanandriana Jaqueline & CE & 102 \\
\hline & Mme Rakotoarimanana Anjarasoa & CE & 94 \\
\hline TOTAL & & & 452 \\
\hline
\end{tabular}

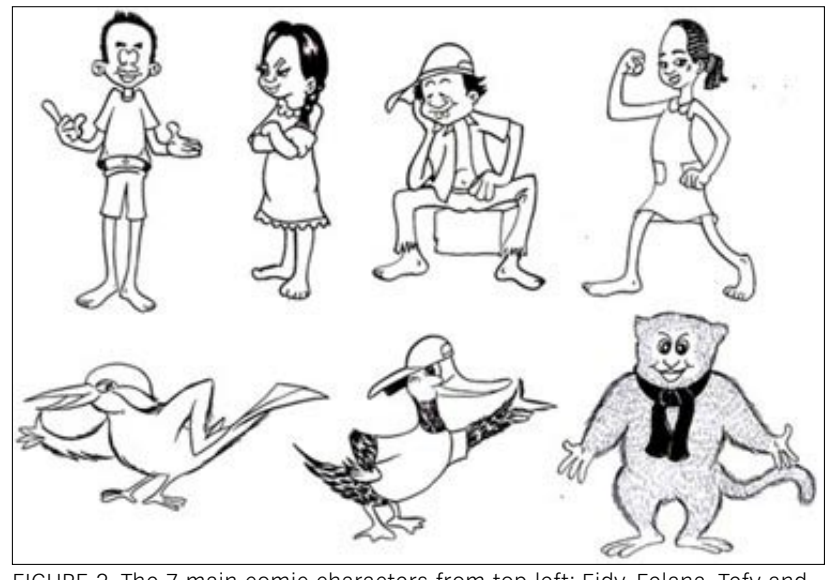

FIGURE 2. The 7 main comic characters from top left: Fidy, Felana, Tefy and Lalao, representing the villagers and from bottom left: Haja, Solofo and Malala, representing the wildlife.

fundamental environmental problems and other related subjects. They also will be informed in detail about the comic and provided with supporting educational material. At the beginning of the 2006-2007 school year, MWC were provide these schools with comic paperbacks. After a four months test phase, MWC will use a questionnaire to evaluate the influence of the environmental education programme on the understanding of the environmental complexities of the lake and marsh system by the test pupils as compared to the control classes (from other villages than of the test classes). MWC aims to have the environmental education implemented in all EPPS of the Alaotra region by 2016.

\section{ACKNOWLEDGEMENTS}

First of all, MWC thanks the CISCO of Amparafaravola and Ambatondrazaka and the CIREF (the regional division of the Ministry of Water \& Forests) for their collaboration and interest in the comic project. MWC is glad to work with the "Parc Ivoloina" (Madagascar Fauna Group, MFG) in the training of the teachers and would like to thank Karen Freeman (MFG) and Andrea Katz (Lemur Center, Duke University) for their support on this article. MWC is gratefully to Susanne Hagen for her critical comments and to Joleen Timko (University of British Columbia) for her helpful comments and proofreading on the latest version of the article.

\section{REFERENCES}

Bakoariniaina, L.N., Kusky, T. and Raharimahefa, T. 2006. Disappearing Lake Alaotra: Monitoring catastrophic erosion, waterway silting, and land degradation hazards in Madagascar using Landsat imagery. Journal of African Earth Sciences, 44: 240-252
Moreau, J. 1987. Madagascar. In African wetlands and shallow water bodies: Directory, M. J. Burgis, and J. J. Symoens, (eds.) pp 595-606. Paris: ORSTOM.

Démographie, in Monographie des Districts, 2004. In Plan Régional de développement Alaotra-Mangoro.

Education, in Monographie des Districts 2004. In Plan Régional de développement Alaotra-Mangoro.

Mutschler, T. and Feistner, A. T. C. 1995. Conservation status and distribution of the Alaotra Gentle Lemur Hapalemur griseus alaotrensis. Oryx 29:267-74

Nicoll, M. E. and Langrand, O. 1989. Madagascar: Revue de la Conservation et des Aires Protégées. World Wide Fund for Nature, Gland, Switzerland.

Pidgeon, M. 1996. An ecological survey of Lake Alaotra and selected wetlands of central and eastern Madagascar in analysing the demise of Madagascar Pochard Aythia innotata. St. Louis: WWF/Missouri Botanical Gardens.

Population, in Monographie des Districts, 2004. In Plan Régional de développement Alaotra-Mangoro.

Ralainasolo, F.B. 2004. Influence des effets anthropiques sur la dynamique de population de Hapalemur griseus alaotrensis ou "Bandro" dans son habitat naturel. Lemur News Vol.9 32-35

Trappe, P. 1987. Soziale Breitenwirkung einer Entwicklungsintervention, "LaC Alaotra - Grenier de Madagascar", Social Startegies, Vol.19, Basel.

Vaucoulon, P. 1990. Anosingidro Tandindomin-doza (Lemurs in Peril). L>Imprimerie de Wissembourg, France. 